\title{
Lignocellulosic Precursors Used in the Elaboration of Activated Carbon
}

\author{
A. Alicia Peláez-Cid and M.M. Margarita Teutli-León \\ Benemérita Universidad Autónoma de Puebla \\ México
}

\section{Introduction}

Many authors have defined activated carbon taking into account its most outstanding properties and characteristics. In this chapter, activated carbon will be defined stating that it is an excellent adsorbent which is produced in such a way that it exhibits high specific surface area and porosity. These characteristics, along with the surface's chemical nature (which depends on the raw materials and the activation used in its preparation process), allow it to attract and retain certain compounds in a preferential way, either in liquid or gaseous phase. Activated carbon is one of the most commonly used adsorbents in the removal process of industrial pollutants, organic compounds, heavy metals, herbicides, and dyes, among many others toxic and hazardous compounds.

The world's activated carbon production and consumption in the year 2000 was estimated to be $4 \times 10^{8} \mathrm{~kg}$ (Marsh, 2001). By 2005, it had doubled (Elizalde-González, 2006) with a production yield of $40 \%$. In the industry, activated carbon is prepared by means of oxidative pyrolysis starting off soft and hardwoods, peat, lignite, mineral carbon, bones, coconut shell, and wastes of vegetable origin (Girgis et al., 2002; Marsh, 2001).

There are two types of carbon activation procedures: Physical (also known as thermal) and chemical. During physical activation, the lignocellulosic material as such or the previously carbonized materials can undergo gasification with water vapor, carbon dioxide, or the same combustion gases produced during the carbonization. Ammonium persulfate, nitric acid, and hydrogen peroxide have also been used as oxidizing agents (Salame \& Bandoz, 2001). Chemical activation consists of impregnating the lignocellulosic or carbonaceous raw materials with chemicals such as $\mathrm{ZnCl}_{2}, \mathrm{H}_{3} \mathrm{PO}_{4}, \mathrm{HNO}_{3}, \mathrm{H}_{2} \mathrm{SO}_{4}, \mathrm{NaOH}$, or $\mathrm{KOH}$ (ElizaldeGonzález \& Hernández-Montoya, 2007; Girgis et al., 2002). Then, they are carbonized (a process now called "pyrolysis") and, finally, washed to eliminate the activating agent. The application of a gaseous stream such as air, nitrogen, or argon is a common practice during pyrolysis which generates a better development of the material's porosity. Although not commonly, compounds such as potassium carbonate, a cleaner chemical agent (Tsai et al., 2001b; 2001c) or formamide (Cossarutto et al., 2001) have been also used as activating agents. 
Commercial activated carbon is produced as powder (PAC), fibers (FAC), or granules (GAC) depending on its application. It regularly exhibits BET specific surface magnitudes between 500 and $2000 \mathrm{~m}^{2} \mathrm{~g}^{-1}$. However, the so-called "super-activated carbons" exhibit surfaces areas above $3000 \mathrm{~m}^{2} \mathrm{~g}^{-1}$. Activated carbon's macro, meso, and micropore volumes may range from 0.5 to $2.5 \mathrm{~cm}^{3} \mathrm{~g}^{-1}$ (Marsh, 2001).

The adsorption capabilities of activated carbon are very high because of its high specific surface, originated by porosity. Also, depending on what type of activation was used, the carbon's surface may exhibit numerous functional groups, which favor the specific interactions that allow it to act as an ionic interchanger with the different kinds of pollutants.

The activated carbon is commonly considered an expensive material because of the chemical and physical treatments used in its synthesis, its low yield, its production's high energy consumption, or the thermal treatments used for its regeneration and the losses generated meanwhile. However, if its high removal capacity compared to other adsorbents is considered, the cost of production does not turn out to be very high. The search for the appropriate mechanism for its pyrolysis process is an important factor for tackling production costs.

The exhausted material's thermal regeneration (Robinson et al., 2001) consists of drying the wet carbon, pyrolysis of the adsorbed organic compounds, and reactivating the carbon, which generates mass losses up to $15 \%$. The carbon's regeneration can also be accomplished by using water vapor or solvents to desorb the absorbed substances, which, in turn, leads to a new problem regarding pollution. Because of these environmental inconveniences as well as the loss in adsorption capacity and the increase in costs which the regeneration process implies, using new carbon once the old one's surface has been saturated is often preferred.

With the goal of diminishing the cost of producing activated carbon, contemporary research is taking a turn towards industrial or vegetable (lignocellulosic) wastes to be used as raw material, and, then, lessen the cost of production (Konstantinou \& Pashalidis, 2010). Besides, the use of these precursors reduces residue generation in both rural and urban areas.

This chapter presents a twenty-year (1992 - 2011) worldwide research review regarding a large amount of lignocellulosic materials proposed as potential precursors in the production of activated carbon. The most common characteristics that lignocellulosic wastes used in carbon production and the parameters that control porosity development and, hence, the increase in specific surface during carbonization are also mentioned. A comparison between countries whose scientists are interested in carbon preparation from alternative waste lignocellulosic materials by continent is made. The most commonly used agents for chemical, physical, or a combination of both activations methods which precursors undergo are shown. 


\section{Characteristics of the selected raw materials for activated carbon production}

The materials selected nowadays to be potential precursors of activated carbons must fulfill the following demands:

1) They must be materials with high carbon contents and low inorganic compound levels (Tsai et al., 1998) in order to obtain a better yield during the carbonization processes. This is valid for practically every lignocellulosic wastes. They must be plentiful in the region or country where they will be used to solve any specific environmental issue. For example, corncob has been used to produce activated carbon and, according to Tsai et al. (1997), corn grain is a very important agricultural product in Taiwan. The same condition applies for the avocado, mango, orange, and guava seeds in Mexico (Elizalde-González et al., 2007; Elizalde-González \& Hernández-Montoya, 2007, 2008, 2009a, 2009b, 2009c; Dávila-Jiménez et al., 2009). Specifically, Mexico has ranked number one in the world for avocado production, number two for mango, and number four for orange (Salunkhe \& Kadam, 1995). On the other hand, jute stick is abundantly available in Bangladesh and India (Asadullah et al., 2007), from which bio-oil is obtained, and the process's residue has been used to produce activated carbon. Bamboo, an abundant and inexpensive natural resource in Malaysia, was also used to prepare activated carbon (Hameed et al., 2007). Cherry pits are an industrial byproduct abundantly generated in the Jerte valley at Spain's Caceres province (OlivaresMarín et al., 2006). Other important wastes generated in Spain that have also been proposed with satisfying results in the production of activated carbon with high porosity and specific surface area are: olive-mill waste generated in large amounts during the manufacture of olive oil (Moreno-Castilla et al., 2001) and olive-tree wood generated during the trimming process of olive trees done to make their development adequate (Ould-Idriss et al., 2011).

2) The residue generated during consumption or industrial use of lignocellulosic materials regularly represents a high percentage of the source from which it is obtained. For example, mango seed is around 15 to $20 \%$ of manila mango from which it is obtained (Salunkhe \& Kadam, 1995). In the case of avocado, 10 to $13 \%$ of the fruit weight corresponds to the kernel seed and it is garbage after consumption (Elizalde-González et al., 2007). Corn cob is approximately $18 \%$ of corn grain (Tsai et al., 2001b). Orange seeds constitute only about 0.3 $\%$ of the fresh mature fruit (Elizalde-González \& Hernández-Montoya, 2009c), but orange is the most produced and most consumed fruit worldwide (Salunkhe \& Kadam, 1995). Sawdust does not constitute a net percentage of tree residue, rather, it is a waste obtained from wood applications conditioning. However, it has proven to be a good precursor when it is obtained from mahogany (Malik, 2003).

3) They must be an effective and economic material to be used as an adsorbent for the removal of pollutants from both gaseous and liquid systems. Specifically, carbons produced from lignocellulosic precursors have been used to eliminate basic dyes (Elizalde-González et al., 2007; Elizalde-González \& Hernández-Montoya, 2007; Girgis et al., 2002; Hameed et al., 2007; Rajeshwarisivaraj et al., 2001), acid dyes (Elizalde-González et al., 2007; ElizaldeGonzález \& Hernández-Montoya, 2008, 2009a, 2009b, 2009c; Malik, 2003; Rajeshwarisivaraj et al., 2001; Tsai et al., 2001a), reactive dyes (Elizalde-González et al., 2007; Senthilkumaara et al., 2006), direct dyes (Kamal, 2009; Namasivayam \& Kavitha, 2002; Rajeshwarisivaraj et al., 2001), metallic ions such as $\mathrm{Cr}^{4+}, \mathrm{Hg}^{2+}$ and $\mathrm{Fe}^{2+}$ (Rajeshwarisivaraj et al., 2001), $\mathrm{Eu}^{3+}$ 
(Konstantinou \& Pashalidis, 2010), $\mathrm{Cu}^{2+}$ (Dastgheib \& Rockstraw, 2001; Konstantinou \& Pashalidis, 2010; Toles et al., 1997) or $\mathrm{Pb}^{2+}$ (Giraldo \& Moreno-Piraján, 2008), and low molecular mass organic compounds such as phenol (Giraldo \& Moreno-Piraján, 2007; Wu et al., 1999, 2001), chlorophenol (Wu et al., 2001), and nitro phenol (Giraldo \& Moreno-Piraján, 2008). For example, bamboo powder charcoal has demonstrated being an attractive option for treatment of superficial and subterranean water polluted by nitrate-nitrogen (Mizuta et al., 2004). Carbon produced from bamboo waste (Ahmad \& Hammed, 2010) as well as the one obtained from avocado peel (Singh \& Kumar, 2008) have proven effective in diminishing COD during the treatment of cotton textile mill wastewater and wastewater from coffee processing plant, respectively. Carbon molecular sieves for separating gaseous mixtures are another application of activated carbons prepared from lignocellulosic precursors (Ahmad et al., 2007; Bello et al., 2002).

\section{Parameters for activated carbon preparation}

Research has shown that carbons's properties such as specific surface area, porosity, density and mechanical resistance depend greatly on the raw material used. However, it may be possible to modify these parameters changing the conditions in the pyrolysis process of the lignocellulosic materials.

In particular, the most important parameters to be considered while preparing activated carbons from lignocellulosic materials are described below.

\subsection{Activating agent}

$\mathrm{H}_{3} \mathrm{PO}_{4}$ is the most commonly used chemical agent for synthesis of activated carbon. The use of $\mathrm{ZnCl}_{2}$ has declined because of the environmental pollution problems with zinc disposal (Girgis et al., 2002). In the case of physical activation, the use of water vapor and carbon dioxide is preferred to promote the partial oxidation of the surface instead of oxygen, which is too reactive.

\subsection{Mass ratio of precursor and activating agent}

The complete saturation of lignocellulosic precursor must be ensured to develop the adsorbent porosity with the minimum activating agent consumption. This leads a minor consumption of chemical compounds and a better elimination of the excess during the carbon washing process. The effect of the increase in proportion of the impregnation over the carbon porous structure is greater than the one obtained with the increase of carbonizing temperature (Olivares-Marín et al., 2006a).

\subsection{Heating speed}

Regularly, heating ramps with a low speed are used for preparation of activated carbon. This approach allows the complete combustion of material precursor and favors a better porosity development. Rapid heating during pyrolysis produces macroporous residue (Heschel \& Klose, 1995). 


\subsection{Carbonizing temperature}

It has the most influence over the activated carbon's quality during the activating process. It must be at least $400{ }^{\circ} \mathrm{C}$ to ensure the complete transformation of organic compounds (present in lignocellulosic precursors) into graphene structures. The degree of specific surface area development and porosity is incremented on par with the carbonizing temperature (Olivares-Marín et al., 2006b). During physical activation, carbonization temperatures are greater than those needed for chemical activation (Lussier et al., 1994). However, carbonization temperatures used in activated carbon production are generally greater than $400{ }^{\circ} \mathrm{C}$ and temperatures ranging from 120 to $1000{ }^{\circ} \mathrm{C}$ have been used. (Elizalde et al., 2007; Elizalde-González \& Hernández-Montoya, 2008; Rajeshwarisivaraj et al., 2001; Salame \& Bandosz, 2001). It has been reported that carbon obtained from peach pits with temperatures below $700{ }^{\circ} \mathrm{C}$ still have a high content of hydrogen and oxygen (MacDonald \& Quinn, 1996).

\subsection{Carbonizing time}

This parameter must be optimized to obtain the maximum porosity development while still minimizing the material's loss due to an excessive combustion. Bouchelta et al. (2008) have shown that the yield percentage decreases with increase of activation temperature and hold time. Carbonization times ranging from $1 \mathrm{~h}$ (Rajeshwarisivaraj et al., 2001; Wu et al., 1999) up to $14 \mathrm{~h}$ (Rajeshwarisivaraj et al., 2001) have been used in charcoal production.

\subsection{Gas flow speed}

It has been observed that during pyrolysis, the passing on an inert gas, such as $\mathrm{N}_{2}$ or $\mathrm{Ar}$, favors the development in the carbon's porosity. In this case, the flow and the gas type may affect the final properties of the activated carbon. $\mathrm{CO}_{2}$ flow-rate had a significant influence on the development of the surface area of oil palm stones (Lua \& Guo, 2000).

\subsection{Effect of washing process}

During the lignocellulosic residue's pyrolysis, the presence of chemical activating agents generates carbons with a more orderly structure. The later elimination of chemical activating agents, by means of successive washings, will allow a better development of porosity.

\section{Worldwide studied precursors}

Numerous lignocellulosic residues have been selected as potential activated carbon precursors. Among them, there is the wood obtained from several kinds of tree species such as Eucalyptus (Bello et al., 2002; Ngernyen et al., 2006; Rodrígez-Mirasol et al., 1993), pine (Giraldo \& Moreno-Piraján, 2007; Sun et al., 2008), Quercus agrifolia (Robau-Sánchez et al., 2001), wattle (Ngernyen et al., 2006), china fir (Zuo et al., 2010), acacia (Kumar et al., 1992), olive tree (Ould-Idriss et al., 2011), softwood bark (Cao et al., 2002), mahogany sawdust (Malik, 2003), sawdust flash ash (Aworn et al., 2008), and sawdust (Giraldo \& MorenoPiraján, 2008; Zhang et al., 2010), coconut shell (Cossarutto et al., 2001; Giraldo \& MorenoPiraján, 2007; Hayashi et al., 2002; Heschel \& Klose, 1995; Hu et al., 2001; Kannan \& Sundaram, 2001), coconut fiber (Namasivayam \& Kavitha, 2002; Phan et al., 2006; Senthilkumaara et al., 2006), corn cob (Aworn et al., 2008; Tsai et al., 1997; 1998; 2001a; 
2001b; Tseng \& Tseng, 2005; Wu et al., 2001), cherry stones (Gergova et al., 1993; 1994; Heschel \& Klose, 1995; Lussier et al., 1994; Olivares-Marín et al., 2006a; 2006b), apricot stones (Gergova et al., 1993; 1994), peach stones (Heschel \& Klose, 1995; MacDonald \& Quinn, 1996; Molina-Sabio et al., 1995; 1996; Rodríguez-Reinoso \& Molina-Sabio, 1992) and peach seed (Giraldo \& Moreno-Piraján, 2007), mixture of apricot and peach stones (Puziy et al., 2005), wheat straw (Kannan \& Sundaram, 2001), rice straw (Ahmedna et al., 2000) and rice husks (Ahmedna et al., 2000; Aworn et al., 2008; Kalderis et al., 2008; Kannan \& Sundaram, 2001; Malik, 2003; Swarnalatha et al., 2009), sugarcane bagasse (Ahmedna et al., 2000; Aworn et al., 2008; Giraldo \& Moreno-Piraján, 2007; Juang et al., 2002; 2008; Kalderis et al., 2008; Tsai et al., 2001;), palm fiber (Guo et al., 2008), palm pit (Giraldo \& Moreno-Piraján, 2007; 2008), palm shell (Ahmad et al., 2007; Arami-Niya et al., 2010; Hayashi et al., 2002), stem of date palm (Jibril et al., 2008), and palm seeds (Gou et al., 2008; Hu et al., 2001), palm stones (Lua \& Guo, 2000), pecan shells (Ahmedna et al., 2000; Dastgheib \& Rockstraw, 2001; Toles et al., 1997), almond shells (Gergova et al., 1994; Hayashi et al., 2002; Iniesta et al., 2001; Mourao et al., 2011; Nabais et al., 2011; Rodríguez-Reinoso \& Molina-Sabio, 1992; Toles et al., 1997), macadamia shells (Aworn et al., 2008; Evans et al., 1999), cedar nut shells (Baklanova et al., 2003), hazelnut shells (Heschel \& Klose, 1995), pistachio shell (Hayashi et al., 2002), and walnut shells (Hayashi et al., 2002; Heschel \& Klose, 1995), bamboo powder (Ahmad \& Hameed, 2010; Hammed et al., 2007; Kannan \& Sundaram, 2001; Mizuta et al., 2004), jute fibers (Asadullah et al., 2007; Phan et al., 2006; Senthilkumaara et al., 2006), plum kernels (Heschel \& Klose, 1995; Wu et al., 1999), avocado kernel seeds (Elizalde-González et al., 2007) and avocado peel (Devi et al., 2008), coffee bean husks (Baquero et al., 2003), coffee residue (Boudrahem et al., 2009), and coffee ground (Evans et al., 1999), date stones (Bouchelta et al., 2008; Hazourli et al., 2009), grape seeds (Gergova et al., 1993, 1994), vine shoot (Mourao et al., 2011), orange seeds (Elizalde-González \& Hernández-Montoya, 2008, 2009c) and guava seeds (Elizalde-González \& Hernández-Montoya, 2008, 2009a, 2009b), mango pit (husk and seed) (Dávila-Jimenez et al., 2009; Elizalde-González \& HernándezMontoya, 2007; 2008), olive stones (Rodríguez-Reinoso \& Molina-Sabio, 1992; Yavuz et al., 2010) and olive cake (Konstantinou \& Pashalidis, 2010; Moreno-Castilla et al., 2001), peanut hull (Girgis et al., 2002; Kannan \& Sundaram, 2001), cassava peel (Rajeshwarisivaraj et al., 2001), pomegranate peel (Amin, 2009), cotton stalks (Girgis \& Ishak, 1999), kenaf (ValenteNabais et al., 2009), cork waste (Carvalho et al., 2004), flamboyant pods (A.M.M. Vargas et al., 2011), rapeseed (Valente-Nabais et al., 2009), Macuna musitana (Vargas et al., 2010), and seed husks of Moringa Oleifera (Warhurst et al., 1997). Table 1 shows clearly the lignocellulosic precursors used in activated carbon production classified according to the source they were obtained from.

Figure 1 shows the great variety of lignocellulosic residues used in worldwide production of activated carbon. It can be observed that wood from several tree species, several kinds of nuts, or different coconut parts are among the most commonly used along with the traditional raw materials used for the preparation of activated carbon. This figure shows that from a single vegetable, different parts have been tested as precursors. For example, the seed and peel of avocado have been studied (Elizalde et al., 2007; Singh \& Kumar, 2008). The same condition applies for the rice straw (Ahmedna et al., 2000) and the rice husk (Kalderis et al., 2008; Swarnalatha et al., 2009). Note that when carbons are prepared with lignocellulosic precursors, they are called charcoal. If they are of mineral origin, then they 
are called coal. Both kinds are susceptible to chemical, physical, or a combination of both activation types to produce the outstanding activated carbons.

It has been found that the activated carbon's properties depend greatly on the composition of their raw materials (Gergova et al., 1993; Girgis et al., 2002). Development of porosity and active sites with a specific character is aided by physical activation because a partial oxidation occurs, and the carbon's surface is enriched with several functional groups (Salame \& Bandoz, 2001). Chemical activation further develops these characteristics. Additionally, chemical activation has several advantages over physical activation. Besides, it is done at lower temperatures. Some authors have chosen a combination of both methods to produce their activated carbons for fitting specific applications. For example, it can be cited the activated carbon obtained from coconut peel activated with water vapor and then treated with formamide to accomplish the adsorption of the vapor (Cossarutto et al., 2001). On the other hand, there are wood carbons chemically activated with $\mathrm{H}_{3} \mathrm{PO}_{4}$ and $\mathrm{KOH}$, and then treated with ammonia persulfate, nitric acid, or hydrogen peroxide (as oxidating agents) with the objective of obtaining carbons either with the nitro- group with positive charges on the nitrogen atom or with negative charges on the oxygen atoms, making them better adsorbents for ionic species (Salame \& Bandoz, 2001).

\begin{tabular}{|c|c|c|c|c|c|}
\hline \multirow{11}{*}{ Wood } & Eucalyptus & \multirow{7}{*}{ Nuts Shells } & Pecan & \multirow{6}{*}{ Palm } & Fiber \\
\hline & Pine & & Almond & & Pit \\
\hline & Quercus agrifolia & & Macadamia & & Shell \\
\hline & Wattle & & Cedar & & Stem of date \\
\hline & China fir & & Hazelnut & & Seeds \\
\hline & Acacia & & Pistachio & & Stones \\
\hline & Olive tree & & Walnut & \multirow{2}{*}{ Coconut } & Shell \\
\hline & Softwood bark & \multirow{6}{*}{ Stones } & Cherry & & Fiber \\
\hline & Mahogany sawdust & & Apricot & \multirow{2}{*}{ Straw } & Rice \\
\hline & Sawdust flash ash & & Peach & & Wheat \\
\hline & Sawdust & & Plum & \multirow{3}{*}{ Peel } & Avocado \\
\hline \multirow{9}{*}{ Seeds } & Peach & & Date & & Cassava \\
\hline & Plum & & Olive & & Pomegranate \\
\hline & Avocado & \multirow{4}{*}{ Husks } & Rice & \multirow{2}{*}{ Jute } & Fibers \\
\hline & Grape & & Coffee bean & & Stick \\
\hline & Orange & & Mango & \multirow{2}{*}{ Coffee } & Ground \\
\hline & Guava & & Moringa Oleifera & & Residue \\
\hline & Mango & Corncob & Peanut hull & Rapeseed & Cork waste \\
\hline & Macuna musitana & Kenaf & Cotton stalks & \multicolumn{2}{|c|}{ Flamboyant pods } \\
\hline & Sugarcane bagasse & Vine shoot & Olive cake & \multicolumn{2}{|c|}{ Bamboo powder } \\
\hline
\end{tabular}

Table 1. Waste materials used in activated carbon production grouped according to their source.

Although some carbons obtained from corn cob with a BET specific surface up to $2595 \mathrm{~m}^{2} \mathrm{~g}^{-1}$ have been prepared via chemical activation with $\mathrm{KOH}$ (Tseng \& Tseng, 2005), high surface areas can be obtained by means of physical activation. These carbons reach values of 1400 $\mathrm{m}^{2} \mathrm{~g}^{-1}$ or more using Eucaliptus as the precursor and $\mathrm{CO}_{2}$ as an oxydating agent (Ngernyen et 
al., 2006; Rodríguez-Mirasol et al., 1993). Figure 2 shows that the worldwide tendency in relationship with the activation type indicates that activated carbons are physically prepared in greater amounts. This tendency may be due to the fact that the best activated carbons for adsorbing of species with positive charges are those oxidized with acid functional groups. The development of these acid groups can be done via oxidation with oxygen present in the air or using some other oxidating materials such as water vapor or carbon dioxide (Dastgheib \& Rockstraw, 2001). Besides, with physical activation, there is no consumption of chemical activating agents. This simplifies the preparation of activated carbons in terms of avoiding the washing procedure involved in the chemical activation and the pollution caused by this procedure.

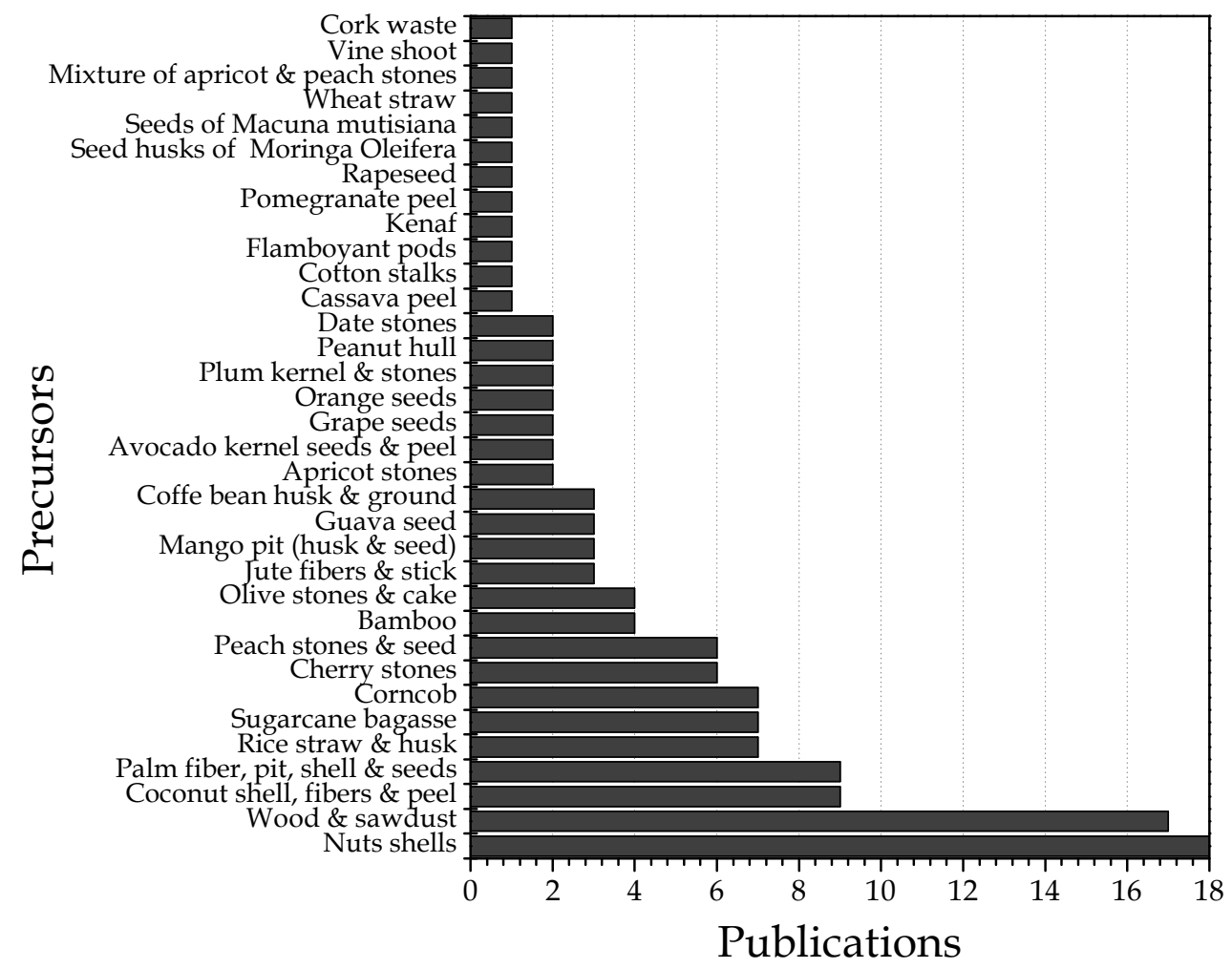

Figure 1. Lignocellulosic raw materials used in the production of activated carbon. Wood includes several varieties such as Acacia, Eucalyptus, fir, mahogany, olive, pine, and wattle. Almond, cedar, hazelnut, macadamia, pecan, pistachio, and, walnut are included in the nuts shells class.

Figure 2 also shows that some authors have also opted for combining activation methods. They use some of the most common chemical agents and then employ streams of diverse oxidating agents in place of inert gases. 


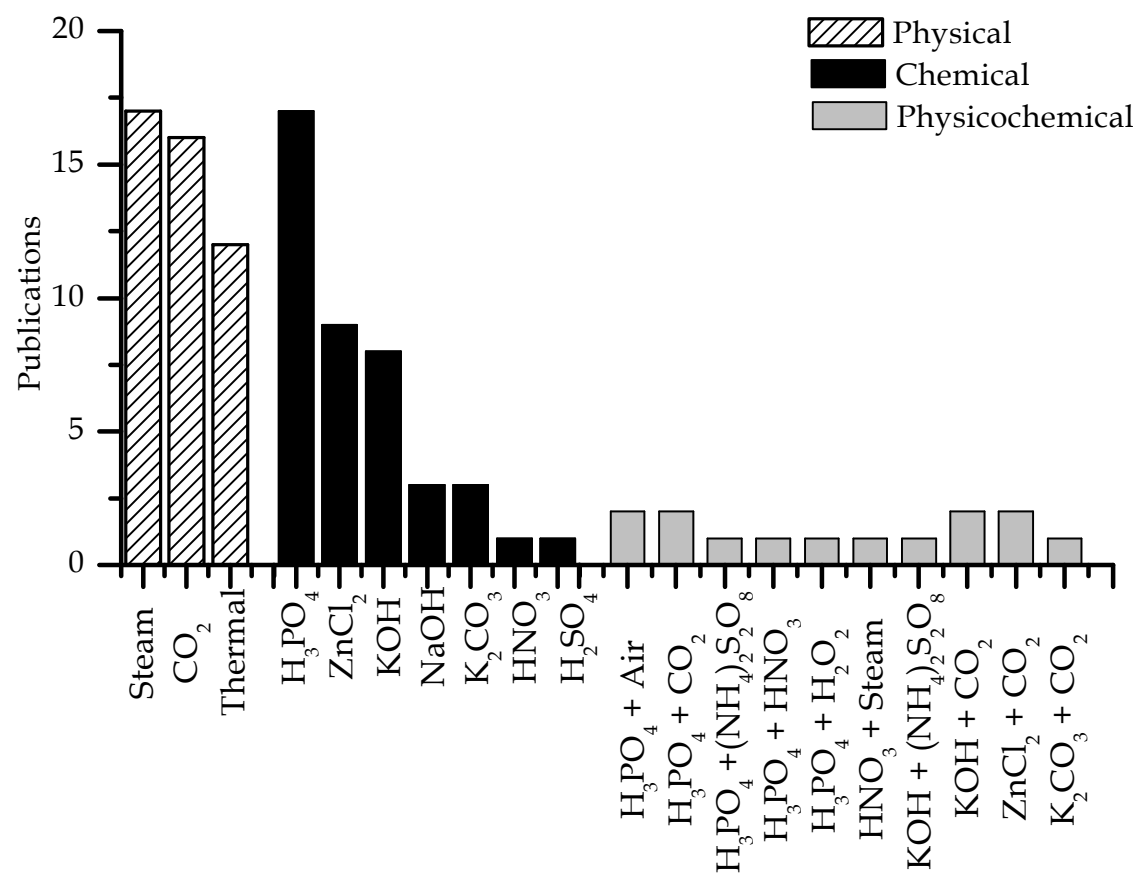

Figure 2. Comparison between the different types of activation and activating agents used in the preparation of activated carbons from lignocellulosic residues.

As a result of the review done, see Figure 3, the different countries' participation in the production of activated carbon was established for this chapter. Asia is the continent with the most research done for the reduction of costs in the production of activated carbon, followed by Europe and America. In Asia, with the exception of Japan, all the countries that participated in the research can be considered underdeveloped, same as America, with the exception of the USA and Canada. It could be thought that the USA has a high degree of research because it is a leading country in terms of technological development in many areas of knowledge. Regarding Europe, it is clear its low participation in this research field. Only Spanish researchers seem to be interested in the activated carbon production problem and they have reported the use of the diverse residues generated in their country for activated carbon preparation. In Africa, because of its underdeveloped economies, only Egypt, Algeria and Moroco participate in this research topic.

Even though the generalized tendency regarding the production of activated carbon leads towards the use of lignocellulosic materials, these can be produced from any carbon-based material (Girgis et al., 2002). Other non-conventional materials that have also been tested are the following: waste slurry of fertilizer plants and blast furnace waste (Gupta et al., 1997), bituminous coal (H. Teng et al., 1997, 1998), paper mill sludge (Khalili et al., 2000), bagasse fly ash (Gupta et al., 2000), waste tires (H. Teng et al., 2000), anthracite (Lillo-Ródenas et al., 2001; Lozano-Castelló et al., 2001), sewage sludge plus coconut husk (Graham et al., 2001; 
Tay et al., 2001), sewage sludge (Graham et al., 2001), sewage sludge plus peanut shell (Graham et al., 2001), sewage sludge of derived fertilizer (Bagreev et al., 2001), viscose rayon (Ko et al., 2002), corrugated paper plus silica (Okada et al., 2005), resorcinol-formaldehyde resin (Elsayed et al., 2007), cattle manure compost (Kian et al., 2008), among others.

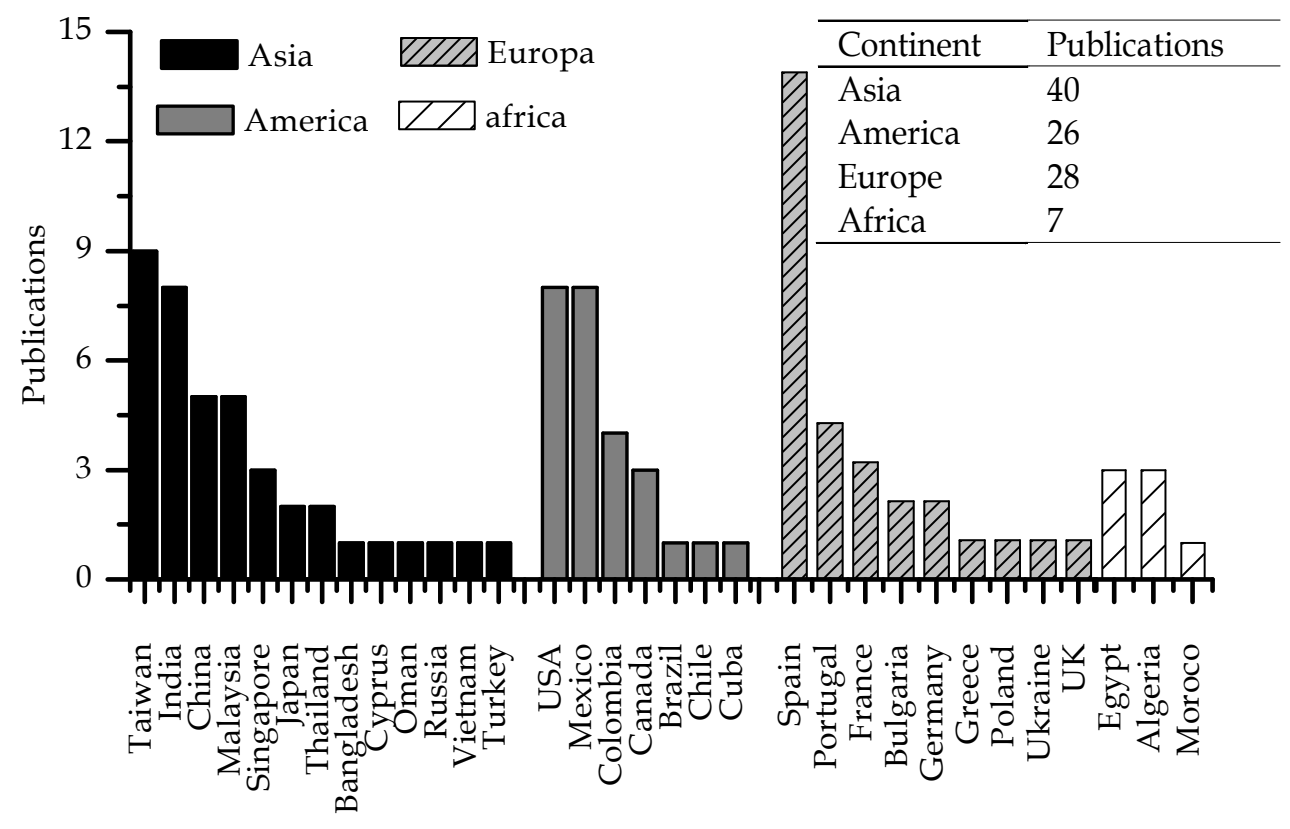

Figure 3. Worldwide distribution and production of activated carbon obtained from lignocellulosic wastes.

\section{Conclusion}

The literature review (1992 - 2011) indicates that worldwide researchers try to propose new sources to obtain raw materials for the production of activated carbon. They have in mind not only to lessen its cost of production, but also to diminish environmental impact of agricultural and industrial wastes. The way to enhance the adsorptive qualities of the carbons produced is also being studied to make its production more profitable, and, hence, solve specific environmental issues.

\section{References}

[1] Ahmad, A.A. \& Hameed, B.H. (2010). Effect of preparation conditions of activated carbon from bamboo waste for real textile wastewater. Journal of Hazardous Materials, Vol. 173, No. 1-3, (January 2010), pp. (487-493), ISSN 0304-3894.

[2] Ahmad, M.A., Wan-Daud, W.M.A. \& Aroua, M.K. (2007). Synthesis of carbon molecular sieves from palm shell by carbon vapor deposition. Journal of Porous Mater, Vol. 14, No. 4, (March 2007), pp. (393-399), ISSN 0165-2370. 
[3] Ahmedna, M., Marshall, W.E. \& Rao, R.M. (2000). Production of granular activated carbons from select agricultural by-products and evaluation of their physical, chemical and adsorption properties. Bioresource Technology, Vol. 71, No. 2, (January 2000), pp. (113-123) ISSN 0960-8524.

[4] Amin, N.K. (2009). Removal of direct blue-106 dye from aqueous solution using new activated carbons developed from pomegranate peel: Adsorption equilibrium and kinetics. Journal of Hazardous Materials, Vol. 165, No. 1-3, (June 2009), pp. (52-62), ISSN 0304-3894.

[5] Arami-Niya, A., Daud, W.M.A.W. \& Mjalli, F.S. (2010). Using granular activated carbon prepared from oil palm shell by $\mathrm{ZnCl} 2$ and physical activation for methane adsorption. Journal of Analytical and Applied Pyrolysis, Vol. 89, No. 2, (November 2010), pp. (197-203), ISSN 0165-2370.

[6] Asadullah, M., Rahman, M.A., Motin, M.A. \& Sultan, M.B. (2007). Adsorption studies on activated carbon derived from steam activation of jute stick char. Journal of Surface Science E Technology, Vol. 23, No. 1-2, pp. (73-80), ISSN 0970-1893.

[7] Aworn, A., Thiravetyan, P. \& Nakbanpote W. (2008). Preparation and characteristics of agricultural waste activated carbon by physical activation having micro- and mesopores. Journal of Analytical and Applied Pyrolysis, Vol. 82, No. 2, (July 2008), pp. (279-285), ISSN 0165-2370.

[8] Bagreev, A., Bandosz, T. J. \& Locke, D.L. (2001). Pore structure and surface chemistry of adsorbents obtained by pyrolysis of sewage sludge-derived fertilizer. Carbon, Vol. 39, No. 13, (November 2001), pp. (1971-1979), ISSN 0008-6223.

[9] Baklanova, O.N., Plaksin, G.V., Drozdov, V.A., Duplyakin, V.K., Chesnokov, N.V., Kuznetsov, B.N. (2003). Preparation of microporous sorbents from cedar nutshells and hydrolytic lignin. Carbon, Vol. 41, No. 9, (June 2003), pp. (1793-1800), ISSN 0008-6223.

[10] Baquero, M.C., Giraldo, L., Moreno, J.C., Suárez-García, F., Martínez-Alonso, A. \& Tascón, J.M.D. (2003), Activated Carbons by pyrolysis of coffee bean husks in presence of phosphoric acid. Analytical Applied Pyrolysis, Vol. 70, No. 2, (December 2003) pp. (779-784), ISSN 0165-2370.

[11] Bello, G., García, R., Arriagada, R., Sepúlveda-Escribano, A., Rodríguez-Reinoso, F. (2002). Carbon molecular sieves from Eucalyptus globulus charcoal. Microporous and Mesoporous Materials, Vol. 56, No. 2, (November 2002), pp. (139-145), ISSN 1387-1811.

[12] Bouchelta, C., Medjram, M.S., Bertrand, O. \& Bellat, J.P. (2008). Preparation and characterization of activated carbon from date stones by physical activation with steam. Journal of Analytical and Applied Pyrolysis, Vol. 82, No. 1, (July 2008), pp. (70-77), ISSN 0165-2370.

[13] Boudrahem, F., Aissani-Benissad, F. \& Aït-Amar, H. (2009). Batch sorption dynamics and equilibrium for the removal of lead ions from aqueous phase using activated carbon developed from coffee residue activated with zinc chloride. Journal of Environmental Management, Vol. 90, No. 10, (July 2009), pp. (3031-3039), ISSN 0301-4797.

[14] Cao, N., Darmstadt, H., Soutric, F. \& Roy, Ch. (2002). Thermogravimetric study on the steam activation of charcoals obtained by vacuum and atmospheric pyrolysis of softwood bark residues. Carbon, Vol. 40, No. 4, (April 2002), pp. (471-479), ISSN 0008-6223.

[15] Carvalho, A.P., Gomes, M., Mestre, A.S., Pires, J. \& Brotas de Carvalho, M. (2004). Activated carbons from cork waste by chemical activation with $\mathrm{K} 2 \mathrm{CO} 3$. Application to adsorption of natural gas components. Carbon, Vol. 42, No. 3, (January 2004), pp. (66769), ISSN 0008-6223. 
[16] Cossarutto, L., Zimny, T., Kaczmarczyk, J., Siemieniewska, T., Bimer, J., \& Weber, J.V. (2001). Transport and sorption of water vapour in activated carbons. Carbon, Vol. 39, No. 15, (December 2001), pp. (2339-2346), ISSN 0008-6232.

[17] Dastgheib, S.A. \& Rockstraw, D.A. (2001). Pecan shell activated carbon: synthesis, characterization, and application for the removal of copper from aqueous solution. Carbon, Vol. 39, No. 12, (October 2001), pp. (1849-1855), ISSN 0008-6223.

[18] Dávila-Jiménez, M.M., Elizalde-González, M.P. \& Hernández-Montoya V. (2009). Performance of mango seed adsorbents in the adsorption of anthraquinone and azo acid dyes in single and binary aqueous solutions. Bioresource Technology, Vol. 100, No. 24, (December 2009), pp. (6199-6206), ISSN 0960-8524.

[19] Devi, R., Singh, V. \& Kumar, A. (2008). COD and BOD reduction from coffee processing wastewater using Avocado peel carbon. Bioresource Technology, Vol. 99, No. 1, (April 2008), pp. (1853-1860), ISSN 0960-8524.

[20] Elizalde-González, M.P. \& Hernández-Montoya, V. (2007). Characterization of mango pit as a raw material in the preparation of activated carbon for wastewater treatment. Biochemical Engineering Journal, Vol. 36, No. 3, (October 2007), pp. (230-238), ISSN 1369-703X.

[21] Elizalde-González, M.P. \& Hernández-Montoya, V. (2008). Fruit seeds as adsorbents and precursors of carbon for the removal of anthraquinone dyes. International Journal of Chemical Engineering, Vol. 1, No. 2-3, pp. (243-253), ISSN 0974-5793.

[22] Elizalde-González, M.P. \& Hernández-Montoya, V. (2009). Guava seed as adsorbent and as precursor of carbon for the adsorption of acid dyes. Bioresource Technology, Vol. 100, No. 7, (April 2009), pp. (2111-2117), ISSN 0960-8524.

[23] Elizalde-González, M.P. \& Hernández-Montoya, V. (2009). Removal of acid orange 7 by guava seed carbon: A four parameter optimization study. Journal of Hazardous Materials, Vol. 168, No. 1, (August 2009), pp. (515 - 522), ISSN 0304-3894.

[24] Elizalde-González, M.P. \& Hernández-Montoya, V. (2009). Use of wide-pore carbons to examine intermolecular interactions during adsorption of anthraquinone dyes from aqueous solution. Adsorption Science E Technology, Vol. 27, No. 5, (June 2009), pp. (447459), ISSN 0263-6174.

[25] Elizalde-González, M.P. (2006). Development of non-carbonised natural adsorbents for removal of textile dyes. Trends in Chemical Engineering, Vol. 10, pp. (55-66), ISSN 0972-4478.

[26] Elizalde-González, M.P., Mattusch, J., Peláez-Cid, A.A. \& Wennrich, R. (2007). Characterization of adsorbent materials prepared from avocado kernel seeds: Natural, activated and carbonized forms. Journal of Analytical and Applied Pyrolysis, Vol. 78, No. 1, (January 2007), pp. (185-193), ISSN 0165-2370.

[27] Elsayed, M.A., Hall, P.J. \& Heslop, M.J. (2007). Preparation and structure characterization of carbons prepared from resorcinol-formaldehyde resin by $\mathrm{CO}_{2}$ activation. Adsorption, Vol. 13, No. 3-4, pp. (299-306).

[28] Evans, M.J.B., MacDonald, J.A.F. \& Halliop, E. (1999). The production of chemicallyactivated carbon. Carbon, Vol. 37, No. 2, (February 1999), pp. (269-274), ISSN 0008-6223.

[29] Gergova, K., Petrov, N. \& Minkova, V. (1993). A comparison of adsorption characteristics of various activated carbons. Journal of Chemical Technology and Biotechnology, Vol. 56, No. 1, (April 2007 on line), pp. (77-82), ISSN 1097-4660.

[30] Gergova, K., Petrov, N. \& Eser, S. (1994). Adsorption properties and microstructure of activated carbons produced from agricultural by-products by steam pyrolysis. Carbon, Vol. 32, No. 4, (May 1994), pp. (693-702), ISSN 0008-6223. 
[31] Giraldo, L. \& Moreno-Piraján, J.C. (2007). Calorimetric determinations of activated carbons in aqueous solution. Journal of Thermal Analysis and Calorimetry, Vol. 89, No.2, pp. (589-594), ISSN 1388-6150.

[32] Giraldo, L. \& Moreno-Piraján, J. C. (2008). $\mathrm{Pb}^{2+}$ adsorption from aqueous solutions on activated carbons obtained from lignocellulosic residues. Brazilian Journal of Chemical Engineering, Vol. 25, No.1, (Jan./Mar. 2008), ISSN 0104-6632.

[33] Girgis, B.S. \& Ishak, M.F. (1999). Activated carbon from cotton stalks by impregnation with phosphoric acid. Materials Letters, Vol. 39, No. 2, (April 1999), pp. (107-114), ISSN 0167-577X.

[34] Girgis, B.S., Yunis, S.S. \& Soliman, A.M. (2002). Characteristics of activated carbon from peanut hulls in relation to conditions of preparation. Materials Letters, Vol. 57, No. 1, (November 2002), pp. (164-172), ISSN 0167-577X.

[35] Graham, N., Chen, X.G. \& Jayaseelan, S. (2001). The potential application of activated carbon from sewage sludge to organic dyes removal. Water Science and Technology, Vol. 43, No. 2, pp. (245-252), ISSN 0273-1223.

[36] Guo, J., Gui, B., Xiang, S., Bao, X., Zhang, H., Lua, A.C. (2008). Preparation of activated carbons by utilizing solid wastes from palm oil processing mills. Journal of Porous Mater, Vol. 15, No. 5, (December 2003), pp. (535-540), ISSN 0165-2370.

[37] Gupta, V.K., Srivastava, S.K. \& Mohan, D. (1997). Equilibrium uptake, sorption dynamics, process optimization, and column operation for the removal and recovery of malachite green from wastewater using activated carbon and activated slag. Industrial and Engineering Chemistry Research, Vol. 36, No.6, (June 1997), pp. (2207-2218), ISSN 0888-5885.

[38] Gupta, V.K., Mohan, D., Sharma, S. \& Sharma M. (2000). Removal of basic dyes (Rhodamine B and Methylene Blue) from aqueous solution using bagasse fly ash. Separation Science E Technology, Vol. 35, No. 13, pp. (2097 - 2113), ISSN 0149-6395.

[39] Hameed, B.H., Din, A.T.M. \& Ahmad, A.L. (2007). Adsorption of methylene blue onto bamboo-based activated carbon: Kinetics and equilibrium studies. Journal of Hazardous Materials, Vol. 141, No.3, (March 2007), pp. (819-825), ISSN 0304-3894.

[40] Hayashi, J., Horikawa, T., Takeda, I., Muroyama, K. \& Ani, F.N. (2002). Preparing activated carbon from various nutshells by chemical activation with $\mathrm{K} 2 \mathrm{CO}$. Carbon, Vol. 40, No. 13, (November 2002), pp. (2381-2386), ISSN 0008-6223.

[41] Hazourli, S., Ziati, M. \& Hazourli A. (2009). Characterization of activated carbon prepared from lignocellulosic natural residue:-Example of date stones-. Physics Procedia, Vol. 2, No.3, pp. (1039-1043), ISSN 1875-3892.

[42] Heschel, W. \& Klose, E. (1995). On the suitability of agricultural by-products for the manufacture of granular activated carbon. Fuel, Vol. 74, No. 12, (December 1995), pp. (1786-1791), ISSN 0016-2361.

[43] Hu, Z., Srinivasan, M.P. \& Ni, Y. (2001). Novel activation process for preparing highly microporous and meso porous activated carbons. Carbon, Vol. 39, No. 6 (May 2001), pp. (877-886), ISSN 0008-6223.

[44] Iniesta, E., Sánchez, F., García, A.N. \& Marcilla, A. (2001).Yields and CO2 reactivity of chars from almond shells obtained by a two heating step carbonisation process. Effect of different chemical pre-treatments and ash content. Journal of Analytical and Applied Pyrolysis, Vol. 58-59 (April 2001), pp. (983-994), ISSN 0165-2370. 
[45] Jibril, B., Houache, O., Al-Maamari, R. \& Al-Rashidi B. (2008). Effects of H3PO4 and $\mathrm{KOH}$ in carbonization of lignocellulosic material. Journal of Analytical and Applied Pyrolysis, Vol. 83, No. 2, (November 2008), pp. (151-156), ISSN 0165-2370.

[46] Juang, R.-S., Wu F.-C. \& Tseng, R.-L. (2002). Characterization and use of activated carbons prepared from bagasses for liquid-phase adsorption. Colloids and Surfaces A, Vol. 201, No. 1-3, (March 2002),pp. (191-199), ISSN 0927-7757.

[47] Kalderis, D., Bethanis, S., Paraskeva, P. \& Diamadopoulos, E. (2008). Production of activated carbon from bagasse and rice husk by a single-stage chemical activation method at low retention times. Bioresource Technology, Vol. 99, No. 15, (October 2008), pp. (6809-6816), ISSN 0960-8524.

[48] Kannan, N. \& Sundaram, M.M. (2001). Kinetics and mechanism of removal of methylene blue by adsorption on various carbons-a comparative study. Dyes and Pigments, Vol. 51, No. 1, (October 2001), pp. (25-40), ISSN 0143-7208.

[49] Khalili, N.R., Campbell, M., Sandi, G. \& Golas, J. (2000). Production of micro-and mesoporous activated carbon from paper mill sludge. I. Effect of zinc chloride activation. Carbon, Vol. 38, No. 14, (November 2000), pp. (1905-1915), ISSN 0008-6223.

[50] Ko, Y.G., Choi, U.S., Kim, J.S. \& Park, Y.S. (2002). Novel synthesis and characterization of activated carbon fiber and dye adsorption modeling. Carbon, Vol. 40, No. 14, (November 2000), pp. (2661-2672), ISSN 0008-6223.

[51] Konstantinou, M. \& Pashalidis, I. (2010). Competitive sorption of $\mathrm{Cu}$ (II) and $\mathrm{Eu}(\mathrm{III})$ ions on olive-cake carbon in aqueous solutions - a potentiometric study. Adsorption, Vol. 16, No. 3, (June 2010), pp. (167-171), ISSN 10450-010-9218-1.

[52] Kumar, M., Gupta, R.C. \& Sharma, T. (1992). Influence of carbonisation temperature on the gasification of Acacia wood chars by carbon dioxide. Fuel Processing Technology, Vol. 32, No. 1-2, (November 1992), pp. (69-76), ISSN 0378-3820.

[53] Lillo-Ródenas, M.A., Lozano-Castelló, D., Cazorla-Amorós, D. \& Linares-Solano, A. (2001). Preparation of activated carbons from Spanish anthracite, II. Activation by NaOH. Carbon, Vol. 39, No. 5, (April 2001), pp. (751-759), ISSN 0008-6223.

[54] Lozano-Castelló, D., Lillo-Ródenas, M.A., Cazorla-Amorós, D. \& Linares-Solano, A. (2001). Preparation of activated carbons from Spanish anthracite, I. Activation by KOH. Carbon, Vol. 39, No. 5, (April 2001), pp. (741-749), ISSN 0008-6223.

[55] Lua, A.C. \& Guo, J. (2000). Activated carbon prepared from oil palm stone by one-step CO2 activation for gaseous pollutant removal. Carbon, Vol. 38, No. 7, (June 2000), pp. (1089-1097), ISSN 0008-6223.

[56] Lussier, M.G., Shull, J.C. \& Miller, D.J. (1994). Activated carbon from cherry stones. Carbon, Vol. 32, No. 8, (November 1994), pp. (1493-1498), ISSN 0008-6223.

[57] MacDonald, J.A.F. \& Quinn, D.F. (1996). Adsorbents for methane storage made by phosphoric acid activation of peach pits. Carbon, Vol. 34, No. 9, (September 1996), pp. (1103-1108), ISSN 0008-6223.

[58] Malik, P.K. (2003). Use of activated carbons prepared from sawdust and rice husk for adsorption of acid dyes: a case study of Acid Yellow 36. Dyes and Pigments, Vol. 56, No. 3, (March 2003), pp. (239-249) ISSN 0143-7208.

[59] Marsh H. (Editor). (2001). Activated carbon compendium, Elsevier Science Ltd, ISBN: 0-08044030-4, UK. 
[60] Mizuta, K., Matsumoto, T., Hatate, Y., Nishihara, K. \& Nakanishi, T. (2004). Removal of nitrate-nitrogen from drinking water using bamboo powder charcoal. Bioresource Technology, Vol. 95, No. 3, (December 2004), pp. (255-257), ISSN 0960-8524.

[61] Molina-Sabio, M., Rodríguez-Reinoso, F., Caturla, F. \& Sellés, M.J. (1995). Porosity in granular carbons activated with phosphoric acid. Carbon, Vol. 33, No. 8, (August 1998), pp. (1105-1113), ISSN 0008-6223.

[62] Molina-Sabio, M., Rodríguez-Reinoso, F., Caturla, F. \& Sellés, M.J. (1996). Development of porosity in combined phosphoric acid-carbon dioxide activation. Carbon, Vol. 34, No. 4, (April 1996), pp. (457-462), ISSN 0008-6223.

[63] Moreno-Castilla, C., Carrasco-Marín, F., López-Ramón, M.V. \& Álvarez-Merino, M.A. (2001). Chemical and physical activation of olive-mill waste water to produce activated carbons. Carbon, Vol. 39, No. 9, (August 2001), pp. (1415-1420), ISSN 0008-6223.

[64] Mourão, P.A.M., Laginhas, C., Custódio, F., Nabais, J.M.V., Carrott, P.J.M. \& RibeiroCarrott M.M.L. (2011). Influence of oxidation process on the adsorption capacity of activated carbons from lignocellulosic precursors. Fuel Processing Technology, Vol. 92, No. 2, (February 2011), pp. (241-246), ISSN 0378-3820.

[65] Nabais, J.M.V., Laginhas, C.E.C., Carrott, P.J.M. \& Ribeiro-Carrott M.M.L. (2011). Production of activated carbons from almond shell. Fuel Processing Technology, Vol. 92, No. 2, (February 2011), pp. (234-240), ISSN 0378-3820.

[66] Namasivayam, C. \& Kavitha, D. (2002). Removal of Congo Red from water by adsorption onto activated carbon prepared from coir pith, an agricultural solid waste. Dyes and Pigments, Vol. 54, No. 1, (July 2002), pp. (47-58), ISSN 0143-7208 .

[67] Ngernyen, Y., Tangsathitkulchai, C. \& Tangsathitkulchai, M. (2006). Porous properties of activated carbon produced from Eucalyptus and Wattle wood by carbon dioxide activation. Korean Journal of Chemical Engineering, Vol. 23, No. 6, pp. (1046-1054), ISSN 0256-1115.

[68] Okada, K., Shimizu, Y.I., Kameshima, Y. \& Nakajima, A. (2005). Preparation and Properties of Carbon/Zeolite Composites with Corrugated Structure. Journal of Porous Materials, Vol. 12, No. 4, pp. (281-291), ISSN 1380-2224.

[69] Olivares-Marín, M., Fernández-González, C., Macías-García, A. \& Gómez-Serrano, V. (2006). Preparation of activated carbon from cherry stones by chemical activation with $\mathrm{ZnCl}_{2}$. Applied Surface Science, Vol. 252, No. 17, (June 2006), pp. (5967-5971), ISSN 0169-4332.

[70] Olivares-Marín, M., Fernández-González, C., Macías-García, A. \& Gómez-Serrano, V. (2006). Preparation of activated carbons from cherry stones by activation with potassium hydroxide. Applied Surface Science, Vol. 252, No. 17, (June 2006), pp. (59805983), ISSN 0169-4332.

[71] Ould-Idriss, A., Stitou, M., Cuerda-Correa, E.M., Fernández-González, C.A., MacíasGarcía, A., Alexandre-Franco, M.F. \& Gómez-Serrano V. (2011). Preparation of activated carbons from olive-tree wood revisited. II. Physical activation with air. Fuel Processing Technology, Vol. 92, No. (July 2010), pp. (266-270), ISSN 0378-3820.

[72] Phan, N.H., Rio, S., Faur, C., Le Coq L., Le Cloirec, P. \& Nguyen, T.H. (2006). Production of fibrous activated carbons from natural cellulose (jute, coconut) fibers for water treatment applications. Carbon, Vol. 44, No. 12, (October 2006), pp. (2569-2577), ISSN 0008-6223.

[73] Puziy, A.M., Poddubnaya, O.I., Martínez-Alonso, A., Suárez-García, F. \& Tascón, J.M.D. (2005). Surface chemistry of phosphorus-containing carbons of lignocellulosic origin. Carbon, Vol. 43, No. 14, (November 2005), pp. (2857-2868), ISSN 0008-6223. 
[74] Qian, Q., Machida, M., Aikawa, M. \& Tatsumoto, H. (2008). Effect of $\mathrm{ZnCl}_{2}$ impregnation ratio on pore structure of activated carbons prepared from cattle manure compost: Application of $\mathrm{N}_{2}$ adsorption desorption isotherms. Journal of Material Cycles Waste Management, Vol. 10, No. 1, pp. (53-61), ISSN 1438-4957.

[75] Rajeshwarisivaraj, Sivakumar, S., Senthilkumar, P. \& Subburam, V. (2001). Carbon from Cassava peel, an agricultural waste, as an adsorbent in the removal of dyes and metal ions from aqueous solution. Bioresource Technology, Vol. 80, No. 3, (December 2001), pp. (233-235), ISSN 0960-8524.

[76] Robau-Sánchez, A., Aguilar-Elguézabal, A. \& De La Torre-Saenz, L. (2001). $\mathrm{CO}_{2}$ activation of char from quercus agrifolia wood waste. Carbon, Vol. 39, No. 9, (August 2001), pp. (1367-1377) ISSN 0008-6223.

[77] Robinson, T., McMullan, G., Marchant, R \& Nigam, P. (2001). Remediation of dyes in textile effluent: a critical review on current treatment technologies with a proposed alternative, Bioresource Technology, Vol. 77, No. 3, (May 2001), pp. (247-255), ISSN 0960-8524.

[78] Rodríguez-Mirasol, J., Cordero, T. \& Rodríguez J.J. (1993). Preparation and characterization of activated carbons from eucalyptus kraft lignin. Carbon, Vol. 31, No. 1, (January 1993), pp. (87-95), ISSN 0008-6223.

[79] Rodríguez-Reinoso, R. \& Molina-Sabio, M. (1992), Activated carbons from lignocellulosic materials by chemical and/or physical activation: An overview. Carbon, Vol. 30, No. 7, (October 1992), pp. (1111-1118), ISSN 0008-6223.

[80] Salame, I.I. \& Bandosz, T.J. (2001). Surface chemistry of Activated Carbons: Combining the results of Temperature-Programmed Desorption, Boehm and Potentiometric Titrations. Journal of Colloids and Interface Science, Vol. 240, No. 1, (August 2001), pp. (252-258), ISSN 0021-9797.

[81] Salunkhe, D.K., \& Kadam, S.S. (Editors). (1995). Handbook of fruit science and technology, production, composition, storage and processing, Marcel Dekker, Inc., ISBN: 0-8247-9643-8, USA.

[82] Senthilkumaar, S., Kalaamani, P., Porkodi, K., Varadarajan, P.R. \& Subburaam, C.V. (2006). Adsorption of dissolved Reactive red dye from aqueous phase onto activated carbon prepared from agricultural waste. Bioresource Technology, Vol. 97, No. 14, (September 2006), pp. (1618-1625), ISSN 0960-8524.

[83] Sun, R.Q., Sun, L.B., Chun, Y. \& Xu, Q.H. (2008). Catalytic performance of porous carbons obtained by chemical activation. Carbon, Vol. 46, No. 13, (November 2008), pp. (1757-1764) ISSN 0008-6223.

[84] Swarnalatha, S., Ganesh-Kumar, A. \& Sekaran, G. (2009). Electron rich porous carbon/silica matrix from rice husk and its characterization. Journal of Porous Mater, Vol. 16, No. 3, pp. (239-245), ISSN 1380-2224.

[85] Tay, J.H., Chen, X.G., Jeyaseelan, S. \& Graham, N. (2001). Optimising the preparation of activated carbon from digested sewage sludge and coconut husk. Chemosphere, Vol. 44, No. 1, (July 2001), pp. (45-51), ISSN 0045-6535.

[86] Teng, H., Ho, J.A. \& Hsu, Y.F. (1997). Preparation of activated carbons from bituminous coals with $\mathrm{CO}_{2}$ activation-influence of coal oxidation. Carbon, Vol. 35, No. 2, (February 1997), pp. (275-283), ISSN 0008-6223.

[87] Teng, H., Yeh, T.S. \& Hsu, L.Y. (1998). Preparation of activated carbon from bituminous coals with phosphoric acid activation. Carbon, Vol. 36, No. 9, (September 1998), pp. (1387-1395), ISSN 0008-6223. 
[88] Teng, Y.C., Lin, L.Y. \& Hsu, H. (2000). Production of activated carbons from pyrolysis of waste tires impregnated with potassium hydroxide. Journal of Air Waste Management Association, Vol. 50, (November 2000), pp. (1940-1946), ISSN 1047-3289.

[89] Toles, C.A., Marshall, W.E., Johns, M.M. (1997). Granular activated carbons from nutshells for the uptake of metals and organic compounds. Carbon, Vol. 35, No. 9, (September 1997), pp. (1407-1414), ISSN 0008-6223.

[90] Tsai, W.T., Chang, C.Y. \& Lee, S.L. (1997). Preparation and characterization of activated carbons from corn cob. Carbon. Vol. 35, No. 8, (November 1997), pp. (1198-1200), ISSN 0008-6223.

[91] Tsai, W.T., Chang, C.Y. \& Lee, S.L. (1998). A low cost adsorbent from agricultural waste corn cob by zinc chloride activation. Bioresource Technology, Vol. 64, No. 3, (June 1998), pp. (211-217), ISSN 0960-8524.

[92] Tsai, W.T., Chang, C.Y., Lin, M.C., Chien, S.F., Sun, H.F. \& Hsieh, M.F. (2001a). Adsorption of acid dye onto activated carbons prepared from agricultural waste bagasse by $\mathrm{ZnCl}_{2}$ activation. Chemosphere, Vol. 45, No. 1, (October 2001), pp. (51-58), ISSN 0045-6535.

[93] Tsai, W.T., Chang, C.Y., Wang, S.Y., Chang, C.F., Chien, S.F. \& Sun, H.F. (2001b). Preparation of activated carbons from corn cob, catalyzed by potassium salts and subsequent gasification with $\mathrm{CO}_{2}$, Bioresource Technology, Vol. 78, No. 2, (June 2001), pp. (203-208), ISSN 0960-8524.

[94] Tsai, W.T., Chang, C.Y., Wang, S.Y., Chang, C.F., Chien, S.F. \& Sun, H.F. (2001c). Cleaner production of carbon adsorbents by utilizing agricultural waste corn cob. Resources, Conservation and Recycling, Vol. 32, No. 1, (May 2001), pp. (43-53), ISSN 0921-3449.

[95] Tseng, R.-L. \& Tseng, S.-K. (2005). Pore structure and adsorption performance of the $\mathrm{KOH}$-activated carbons prepared from corncob. Journal of Colloid and Interface Science, Vol. 287, No. 2, (July 2005), pp. (428-437), ISSN 0021-9797.

[96] Valente-Nabais, J.M., Gomes, J.A., Suhas, Carrott, P.J.M., Laginhas, C. \& Roman, S. (2009). Phenol removal onto novel activated carbons made from lignocellulosic precursors: influence of surface properties, Journal of Hazardous Materials, Vol. 167, No. 1-3, (August 2009), pp. (904-910), ISSN 0304-3894.

[97] Vargas, A.M.M., Cazetta, A.L., Garcia, C.A., Moraes, J.C.G., Nogami, E.M., Lenzi, E., Costa, W.F. \& Almeida, V.C. (2011). Preparation and characterization of activated carbon from a new raw lignocellulosic material: flamboyant (Delonix Regia) pods. Journal of Environmental Management, Vol. 92, No. 1, (January 2011), pp. (178-184), ISSN 0301-4797.

[98] Vargas, J.E., Giraldo, L. \& Moreno-Piraján, J.C. (2010). Preparation of activated carbons from seeds of Macuna mutisiana by physical activation with steam. Journal of Analytical and Applied Pyrolisis, Vol. 89, No. 2, (November 2010), pp. (307-312), ISSN 0165-2370.

[99] Warhurst, A.M., Fowler, G.D., McConnachie, G.L. \& Pollard, S.J.T. (1997). Pore structure and adsorption characteristics of steam pyrolysis carbons from Moringa oleifera. Carbon, Vol. 35, No. 8, (August 1997), pp. (1039-1045), ISSN 0008-6223.

[100] Wu, F.C., Tseng, R.L. \& Juang, R.S. (1999). Pore structure and adsorption performance of the activated carbons prepared from plum kernels. Journal of Hazardous Materials, Vol. 69, No. 3, (November 1999), pp. (287-302), ISSN 0304-3894.

[101] Wu, F.C., Tseng, R.L. \& Juang, R.S. (2001). Adsorption of dyes and phenol from water on the activated carbons prepared from corncob wastes. Environmental Technology, Vol. 22, No. 2, (February 2001), pp. (205-213), ISSN 0959-3330. 
[102] Yavuz, R.; Akyildiz, H.; Karatepe, N. \& Çetinkaya, E. (2010). Influence of preparation conditions on porous structures of olive stone activated by H3PO4. Fuel Processing Technology, Vol. 91, No. 1, (January 2010), pp. (80-87), ISSN 0378-3820.

[103] Zhang, H., Yan, Y. \& Yang, L. (2010). Preparation of activated carbon from sawdust by zinc chloride activation. Adsorption, Vol. 16, No. 3, (August 2010), pp. (161-166).

[104] Zuo, S., Yang, J. \& Liu, J. (2010). Effects of the heating history of impregnated lignocellulosic material on pore development during phosphoric acid activation. Carbon, Vol. 48, No. 11, (September 2010), pp. (3293-3295), ISSN 0008-6223. 


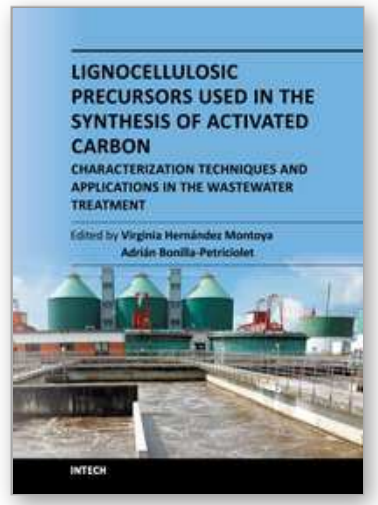

\author{
Lignocellulosic Precursors Used in the Synthesis of Activated \\ Carbon - Characterization Techniques and Applications in the \\ Wastewater Treatment \\ Edited by Dr. Virginia Hernández Montoya
}

ISBN 978-953-51-0197-0

Hard cover, 92 pages

Publisher InTech

Published online 29, February, 2012

Published in print edition February, 2012

The present book discusses the principal lignocellulosic precursors used in the elaboration of activated carbons in different countries such as Asia, America, Europe and Africa; the different methods and experimental conditions employed in the synthesis of activated carbons, including one analysis of the principal stages of the preparation such as carbonization and activation (i.e., chemical or physical activation). Also, the recent and more specialized techniques used in the characterization of activated carbons are discussed in this book. For example, the techniques employed to determine textural parameters (mercury porosimetry and gas adsorption isotherms at $77 \mathrm{~K}$ ) and different spectroscopies to determine chemical functionality (Raman, FT-IR, etc.) and other X-Ray techniques. Additionally, an overview of the application of activated carbons obtained from lignocellulosic precursors for wastewater treatment. Specifically, the analysis and discussion are focused on the advantages and capabilities of activated carbons for the removal of relevant toxic compounds and pollutants from water such as heavy metals, dyes, phenol, etc. Finally, the use of pyrolysis method for the valorization of two Mexican typical agricultural wastes (orange peel and pecan nut shell) for energy and carbon production is considered in this book.

\title{
How to reference
}

In order to correctly reference this scholarly work, feel free to copy and paste the following:

A. Alicia Peláez-Cid and M.M. Margarita Teutli-León (2012). Lignocellulosic Precursors Used in the Elaboration of Activated Carbon, Lignocellulosic Precursors Used in the Synthesis of Activated Carbon - Characterization Techniques and Applications in the Wastewater Treatment, Dr. Virginia Hernández Montoya (Ed.), ISBN: 978953-51-0197-0, InTech, Available from: http://www.intechopen.com/books/lignocellulosic-precursors-used-inthe-synthesis-of-activated-carbon-characterization-techniques-and-applications-in-the-wastewatertreatment/no-title-specified-

\section{INTECH}

open science | open minds

\author{
InTech Europe \\ University Campus STeP Ri \\ Slavka Krautzeka 83/A \\ 51000 Rijeka, Croatia \\ Phone: +385 (51) 770447 \\ Fax: +385 (51) 686166
}

\author{
InTech China \\ Unit 405, Office Block, Hotel Equatorial Shanghai \\ No.65, Yan An Road (West), Shanghai, 200040, China \\ 中国上海市延安西路65号上海国际贵都大饭店办公楼 405 单元 \\ Phone: +86-21-62489820 \\ Fax: +86-21-62489821
}


www.intechopen.com 
(C) 2012 The Author(s). Licensee IntechOpen. This is an open access article distributed under the terms of the Creative Commons Attribution 3.0 License, which permits unrestricted use, distribution, and reproduction in any medium, provided the original work is properly cited. 